\title{
Pelizaeus-Merzbacher disease in female carriers
}

INSERM

\section{Source}

INSERM. (1999). Orphanet: an online rare disease and orphan drug data base. PelizaeusMerzbacher disease in female carriers. ORPHA:280229

Pelizaeus-Merzbacher disease (PMD) in female carriers is the presentation of PMD (see this term) in some women carrying mutations in the PLP1 gene (Xq22). 